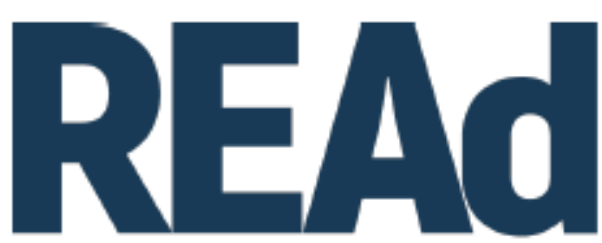

Revista Eletrônica de Administração

\title{
DIFERENÇAS E INTERSECCIONALIDADES NAS ORGANIZAÇÕES: ANÁLISE DAS REPRESENTAÇÕES DE LÍDERES NOS FILMES AMOR SEM ESCALAS, O DIABO VESTE PRADA E UM SENHOR ESTAGIÁRIO ${ }^{1}$
}

\author{
Andreza de Amorim Lima Ferreira ${ }^{2}$ \\ Bárbara do Nascimento Alves ${ }^{3}$ \\ Emanuela Ribeiro Lins ${ }^{4}$ \\ Elisabeth Cavalcante dos Santos ${ }^{5}$
}

http://dx.doi.org/10.1590/1413-2311.305.102062

\begin{abstract}
RESUMO
Abordar a temática dos marcadores sociais da diferença e das interseccionalidades diz respeito a entender suas raízes, consequências e imbricações que produzem e reproduzem desigualdades, resistências e confrontamento das opressões. Neste contexto, as narrativas ficcionais podem constituir formas de representação e produzir insights, pois performam práticas e discursos. Este estudo objetivou analisar os marcadores sociais da diferença e as interseccionalidades representadas na figura do líder organizacional nos filmes Amor sem Escalas, O Diabo veste Prada e Um Senhor Estagiário. No tocante aos procedimentos metodológicos, foi realizada uma pesquisa qualitativa e descritiva, considerando nos filmes, data, sujeitos e lugar. A coleta de dados se deu por meio da microanálise estruturada de cada filme e a discussão ocorreu com base nas categorias de análise dos marcadores sociais da diferença e das interseccionalidades. Conclui-se que as diferenças e interseccionalidades abordadas neste artigo aproximam o contexto organizacional fictício, representado nos filmes examinados, da realidade de muitas organizações, em que se reforçam os padrões normativos através de relações hierárquicas e desiguais. Estas são resultantes do cruzamento dos

\footnotetext{
${ }^{1}$ Recebido em 15/4/2020, aceito em 5/10/2020.

${ }^{2}$ Universidade Federal de Pernambuco (UFPE/CAA) - Programa de Pós-graduação em Gestão, Inovação e Consumo (PPGIC), Caruaru - PE (Brasil); https://orcid.org/0000-0002-0397-4447; andrezamorim15@gmail.com.

${ }^{3}$ Universidade Federal de Pernambuco (UFPE/CAA) - Programa de Pós-graduação em Gestão, Inovação e Consumo (PPGIC), Caruaru - PE (Brasil); https://orcid.org/0000-0002-5042-2063; barbara_gus@ @otmail.com ${ }^{4}$ Universidade Federal de Pernambuco (UFPE/CAA) - Programa de Pós-graduação em Gestão, Inovação e Consumo (PPGIC), Caruaru - PE (Brasil); https://orcid.org/0000-0002-7084-6840; linsmanu41@ gmail.com

${ }^{5}$ Universidade Federal de Pernambuco (UFPE/CAA) - Programa de Pós-graduação em Gestão, Inovação e Consumo (PPGIC), Caruaru - PE (Brasil); https://orcid.org/0000-0003-3133-7290; elisabethcsantos@gmail.com
} 
marcadores sociais da diferença (classe, gênero, raça/etnia, sexualidade e geração), apreendendo um processo de preconceitos interligados, que ocorrem, muitas vezes, de forma sutil e silenciosa na vivência do cotidiano organizacional.

Palavras-chave: Filmes. Interseccionalidade. Líder Organizacional. Marcadores Sociais da Diferença.

\title{
DIFFERENCES AND INTERSECTIONALITIES IN ORGANIZATIONS: ANALYSIS OF LEADER REPRESENTATIONS IN THE FILMS UP IN THE AIR, THE DEVIL WEARS PRADA AND THE INTERN
}

Addressing the theme of social markers of difference and intersectionality concerns understanding their roots, consequences and imbrications that produce and reproduce inequalities, resistance and confrontation of oppression. In this context, fictional narratives can constitute forms of representation and produce insights, as they perform practices and discourses. This study aimed to analyze the social markers of difference and the intersectionality represented in the figure of the organizational leader in the films $U p$ in the Air, The Devil wears Prada and The Intern. Regarding the methodological procedures, a qualitative and descriptive research was done, considering in the films, date, subjects and place. Data collection took place through the structured microanalysis of each film and the discussion took place based on the categories of analysis of the social markers of difference and intersectionality. It is concluded that the differences and intersectionality approached in this article brings the fictitious organizational context, represented in the films examined, closer to the reality of many organizations, in which normative standards are reinforced through hierarchical and unequal relations. These are the result of crossing the social markers of difference (class, gender, race/ethnicity, sexuality and generation), apprehending a process of interconnected prejudices, which often occur in a subtle and silent way in the experience of organizational daily life.

Keywords: Movies. Intersectionality. Organizational Leader. Social Markers of Difference.

\section{DIFERENCIAS E INTERSECCIONALIDADES EN LAS ORGANIZACIONES: ANÁLISIS DE LAS REPRESENTACIONES DE LOS LÍDERES EN LAS PELÍCULAS} ARRIBA EN EL AIRE, EL DIABLO LLEVA PRADA Y EL INTERN

\begin{abstract}
Abordar el tema de los marcadores sociales de la diferencia y la interseccionalidad se refiere a comprender sus raíces, consecuencias e imbricaciones que producen y reproducen desigualdades, resistencia y confrontación de la opresión. En este contexto, las narraciones ficticias pueden constituir formas de representación y producir ideas, a medida que realizan prácticas y discursos. Este estudio tuvo como objetivo analizar los marcadores sociales de la diferencia y las interseccionalidades representadas en la figura del líder organizacional en las películas Arriba en el Aire, El Diablo lleva Prada y El Intern. En cuanto a los procedimientos metodológicos, se realizó una investigación cualitativa y descriptiva, considerando en las películas, fecha, temas y lugar. La recopilación de datos se llevó a cabo a través del microanálisis estructurado de cada película y la discusión se realizó en función de las categorías
\end{abstract}


de análisis de los marcadores sociales de diferencia e interseccionalidad. Se concluye que las diferencias y la interseccionalidad abordada en este artículo acerca el contexto organizacional ficticio, representado en las películas examinadas, más cercano a la realidad de muchas organizaciones, en las cuales los estándares normativos se refuerzan a través de relaciones jerárquicas y desiguales. Estos son el resultado de cruzar los marcadores sociales de la diferencia (clase, género, raza / etnia, sexualidad y generación), aprehender un proceso de prejuicios interconectados, que a menudo ocurren de manera sutil y silenciosa en la experiencia de la vida cotidiana organizacional.

Palabras clave: Películas. Interseccionalidad. Líder Organizacional. Marcadores Sociales de la Diferencia.

\section{INTRODUÇÃO}

Uma temática que vem ganhando espaço nas discussões acerca de diferenças e desigualdades sociais, a qual adentra geralmente os marcadores sociais da diferença de classe, gênero e raça, é a interseccionalidade. Esta é resultante do imbricamento de diversas e simultâneas formas de opressão que tornam aparente os regimes de desigualdades de vários grupos sociais invisibilizados (CRENSHAW, 2002).

A interseccionalidade vem sendo abordada em diferentes contextos: social, político (CRENSHAW, 2002; COLLINS, 2017) e organizacional (ACKER, 2006; HOLVINO, 2010; BERNARDINO-COSTA, 2015) a fim de colocar em destaque a necessidade de analisar conjuntamente as diferenças, as dominações e as múltiplas formas de opressões e graus de desigualdades. Nos estudos organizacionais, a interseccionalidade tem se concentrado em uma ou outra categoria de análise, como: gênero (ECCEL; GRISCI, 2011; PHILLIPS; KNOWLES, 2012; SOUZA, 2017); sexualidade (POMPEU; SOUZA, 2018; MENDES, 2019; POMPEU; SOUZA, 2019); raça (ROSA, 2014); geração (BUTLER, 1969; LOTH; SILVEIRA, 2014; SILVA; HELAL, 2019). Este fato tende a criar barreiras e simplificar as outras realidades interpenetrantes no ambiente organizacional, estabelecendo um grau e um padrão de segregação que pode variar entre as organizações, criando hierarquias entre os empregos nos diferentes níveis da organização (ACKER, 2006; BERNARDINO-COSTA, 2015).

Estudar as diferenças e interseccionalidades permite aprofundar o entendimento acerca do sistema hierárquico e das desigualdades que permeiam o ambiente organizacional. Estes sistemas se mantêm, pois, os cargos de posições superiores nas organizações ainda são formados pela lógica da heteronormatividade masculina, predominando a matriz heterossexual que é regulada pelas normas de gênero e que coloca o homem branco em posições privilegiadas 
(ACKER, 2006; LOTH; SILVEIRA, 2014; POMPEU; SOUZA, 2019). Este sistema hierárquico mantém as compreensões estigmatizadas existentes em torno dos marcadores sociais de diferenças, que geram e reforçam opressões, produzindo simultaneamente sistemas de classificação de tarefas que colocam a mulher, principalmente a mulher não branca, em posição inferior (ACKER, 2006; HOLVINO, 2010; BERNARDINO-COSTA, 2015).

Falar sobre a diferenciação social e suas interseccionalidades diz respeito a entender como as diferenças são construídas com base em sistemas hierárquicos, as consequências dessa construção, em termos de assimetrias, discriminação, desigualdade (SASSEGE et al., 2018) e também de resistências (BRAH, 2006; BERNARDINO-COSTA, 2015). Brah (2006) expõe que a imagem visual constitui formas de representações e práticas. Nesse aspecto, arte, cinema, dança, entre outros comunicam e estabelecem a prática e o discurso dominante.

Narrativas ficcionais podem aprimorar o entendimento a respeito dos processos organizacionais, pois como argumentado por Phillips e Knowles (2012) as formas de se contar uma história provêm de determinado contexto. Sendo assim, a análise dos modos pelos quais os personagens em seus ambientes ficcionais são codificados e constituídos fornece oportunidades para interpretação e discussão das representações de teoria e prática no contexto organizacional (PHILLIPS; KNOWLES, 2012).

Diante o exposto, este estudo se propõe a responder a seguinte problemática: como os marcadores sociais da diferença e as interseccionalidades são representados na figura do/a líder organizacional nos filmes Amor sem Escalas, O Diabo veste Prada e Um Senhor Estagiário? Na tentativa de responder ao problema desta pesquisa, foi elaborado o objetivo geral que buscou analisar os marcadores sociais da diferença e as interseccionalidades representados na figura do/a líder organizacional nos filmes Amor sem Escalas, O Diabo veste Prada e Um Senhor Estagiário.

A escolha dos filmes se deu pelo fato de abordarem o contexto organizacional, destacando a figura do/a líder no enfrentamento de dificuldades específicas no mundo do trabalho, como instabilidade e posições ocupadas no emprego frente a distintas faixas etárias, gênero, raça/etnia, sexualidade e classe. Esses eixos de diferenciação, quando imbricados, representam as diferenças e interseccionalidades presentes nas práticas organizacionais, as quais geram regimes de desigualdades em que alguns são privilegiados e outros discriminados e/ou excluídos (ACKER, 2006). Desse modo, as representações das diferenças e interseccionalidades podem demonstrar aceitação e repetição de comportamentos considerados adequados conforme padrões constituídos pela sociedade, como também, resistências na busca por re-existência (HOLVINO, 2010; MOUTINHO, 2014).

(c) $($ (1) $($ REAd | Porto Alegre - Vol. 26 - N.․ 3 - Setembro / Dezembro 2020 - p. 819-850. 
Além disso, destaca-se que estes filmes são citados no campo da Administração, sendo os mesmos trabalhados nos cursos de graduação e pós-graduação. Esses dados se comprovam nos casos para ensino que abordam esses filmes, como por exemplo, "Precisa-se de um administrador mais experiente?" (LIMA, 2017), "Detalhes de sua incompetência não me interessam": o assédio moral no filme O Diabo veste Prada' (MACIEL; HELAL, 2017) e "E a carreira? Voou pelos ares" (LOPES; SILVA; HELAL, 2015).

Diante dessas considerações, nota-se uma lacuna acerca da pouca quantidade de estudos nacionais que tratam de interseccionalidade no cenário organizacional considerando mais de um marcador social da diferença. Como explanado por Acker (2006, p. 442, tradução nossa) "a maioria dos estudos sobre a produção de desigualdades de classe, gênero e raça em organizações se concentraram em uma ou outra dessas categorias, raramente tentando estudálos como processos complexos, reforçadores ou contraditórios". Desse modo, a autora alude à importância de se atentar às interseccionalidades e suas complexas consequências no contexto laborativo.

Sendo assim, esta pesquisa se justifica pela relevância de realizar estudos que tratem dos marcadores sociais da diferença e das relações hierárquicas de poder que podem estar inscritas em suas articulações, sendo fundamental compreender as construções e representações das interseccionalidades (BRAH; PHOENIX, 2004; BRAH, 2006). Também se demonstra necessário investigar essas representações no contexto organizacional mais especificamente, buscando entender as formas complexas que as práticas de lideranças e os processos organizacionais criam, perpetuam e até mesmo desafiam opressões e discriminações (PHILLIPS; KNOWLES, 2012). Assim, constitui-se fundamental abranger os efeitos das conexões entre gênero, raça e as demais categorias da diferença nos indivíduos, nas suas relações sociais, nos arranjos institucionais, culturais e organizacionais em termos de poder (STEINFIELD et al., 2019), uma vez que os trabalhos nessa temática ainda se demonstram incipientes no contexto organizacional.

Dadas as exposições iniciais, o artigo está organizado em cinco seções, além desta introdutória: inicialmente, aborda-se as diferenças como marcadores sociais, mostrando como eles foram construídos ao longo do tempo; em seguida, concentra-se na contextualização da interseccionalidade, apresentando seu marco histórico e seu conceito na compreensão dos marcadores sociais da diferença de forma interconectada; posteriormente, é trabalhada a interseccionalidade no contexto organizacional a fim de mostrar a relação desta temática na figura do líder; logo depois, discute-se a análise dos filmes, mostrando como as diferenças e 
interseccionalidades são representadas e, finalmente são apresentadas as considerações finais nas quais são expostos os resultados deste estudo.

\section{REFERENCIAL TEÓRICO}

\subsection{AS DIFERENÇAS COMO MARCADORES SOCIAIS}

As diferenças têm sido contextualizadas por meio de diversas perspectivas e estudos, produzindo diferentes discursos e significados. Vale destacar algumas questões que estão envoltas nessas pesquisas: como a diferença deve ser entendida? Como a diferença determina o "outro"? Quem estabelece a diferença? Quais normas imperam e presumem quais grupos sejam diferentes? Como são os indivíduos/grupos representados em distintos discursos da diferença? As percepções da diferença atuam como forma de afirmar a diferença ou gerar práticas excludentes e discriminatórias? Legitimam discursos progressistas ou opressivos? De que modo são representadas diferentes categorias em tais discursos? Como respondem os “diferentes” a essas representações? (BRAH, 2006).

Esses questionamentos são fundamentais para compreender como as diferenças são construídas e constituídas socialmente. Servem também para problematizar e buscar apreender como elas são representadas na figura de líderes organizacionais, conforme propõe este trabalho. Mendes (2019) contextualiza a diferença afirmando que ela pode se referir àquilo que se percebe diferente em si a partir do olhar para o outro, como também para distinguir o outro a partir de referências em si. Petri (2009) complementa afirmando que muito do entendimento que se tem sobre os diferentes são resultados de construções históricas que se institucionalizaram, nas quais os discursos sobre definem os discursos de, produzindo e se reproduzindo, determinando o normal e o anormal.

É relevante pontuar também que existem algumas situações nas quais as diferenças podem ser confundidas com desigualdades ou o contrário, pelo fato de estarem entrelaçadas. Brah (2006), no intuito de explicar essa relação define os dois termos, respectivamente, considerando que a diferença está diretamente relacionada à diversas formas como os discursos são criados, produzidos e contestados. Em contrapartida, as desigualdades dizem respeito a um contexto contingencial, pois nem sempre a diferença gera hierarquia e discriminação, sendo fundamental considerar se a diferença gera desigualdade (BRAH, 2006).

Neste trabalho, parte-se da compreensão de que as assimetrias produzidas em torno das diferenças são resultados de relações de poder-saber, considerando o poder como um elemento 
processual difuso, que circula entre os sujeitos, está inscrito no corpo, do qual é difícil se desprender, e que é fortalecido por aparelhos punitivos e dispositivos de seleção entre "normais" e "anormais" (FOUCAULT, 1979). A partir desse entendimento, diversos autores e autoras se debruçaram sobre o estudo das diferenças, como Scott (1995), que problematiza o gênero enquanto categoria analítica constituída por relações de poder, e Butler (2003), que desconstrói a matriz heterossexual, produtora de sujeitos viáveis e inviáveis em termos de gênero e sexualidade, e que tem como bases lógicas de classificação binárias (homem versus mulher, homo versus heterossexual etc.).

Santos (1999), também utiliza esta compreensão de poder ao investigar processos de exclusão como fenômeno histórico, cultural e social, que designam um discurso de verdade sobre o interdito e o repele. De acordo com o autor, ao excluído e interdito social, resta um lugar que lança para outro lugar, um limite para além do qual impera a transgressão. No alicerce da exclusão existe uma pertença que se alega pela não pertença, que acontece pela normalidade que desqualifica, demonstrando um discurso de fronteiras e segregações. Desse modo, Santos (1999) afirma que os "excluídos foucaultianos" são criados pelos dispositivos de verdade, que estabelece o eu e o outro, "equilibrados" em uma distribuição que exclui ou interdiz tudo que se insere no lado errado da partição; sendo estes dispositivos sustentados pelas práticas, ideologias e ações que interligam a desigualdade e a exclusão sociais.

Tomando por base essa compreensão, a diferença constitui uma construção histórica, um processo social no qual certas "verdades" são consideradas "normais" em um sistema de classificação que promove a desigualdade e a exclusão (SANTOS, 1999; PETRI, 2009; ZAMBONI 2014; NETO, 2017). Desse modo, as diferenças são firmadas por relações de podersaber que designam categorias sociais e identitárias configurando-as como naturais (SOUZA, 2014).

Esses sistemas de classificação são denominados por Zamboni (2014), Saggese et al. (2018) e Hirano, Acunã e Machado (2019) como marcadores sociais da diferença, os quais agrupam indivíduos com características semelhantes, categorizam os mesmos em determinadas posições sociais e definem atribuições específicas a estes grupos, produzindo e reproduzindo as desigualdades. Estes marcadores correspondem à raça/etnia, gênero, sexualidade, classe, geração, entre outros. Na visão de Brah (2006), as diferenças correspondem a categorias de análise, que podem ser compreendidas através de três constatações: (1) as diferenças e desigualdades entre os seres humanos não são naturais, constituem-se dependentes de tempo e espaço; (2) não ocorrem de forma isolada, estão imbricadas nas experiências, nos discursos e 
política construídos socialmente, e; (3) os sistemas de classificação estão intimamente associados às relações de poder e sistemas de dominação.

Como Goffman (1963) argumenta, partindo de uma abordagem interacionista simbólica, esses indivíduos marcados pelas diferenças são estigmatizados. $\mathrm{O}$ autor define estigma como sendo a situação do indivíduo que está inabilitado para a aceitação social plena e destaca que esta não aceitação é proveniente de um processo de formação com intensa participação da sociedade e tem efeitos negativos na vida dos indivíduos estigmatizados. $\mathrm{O}$ autor adentra também nas questões de categorização, dos sistemas de classificação criados ao longo do tempo pela sociedade, estabelecendo nas pessoas preconcepções do que seja "normal", "natural" e "anormal".

Essas constatações evidenciam a relevância de se compreender a evolução na temática da diferença, sendo fundamental destacar alguns aspectos introdutórios a respeito dos principais eixos de distinção tratados nos estudos, os quais, conforme Mendes (2019), variam substancialmente entre si no que se refere ao seguimento do grupo-alvo que buscam alcançar. De acordo com Zamboni (2014), as problematizações que se voltam a essas questões remetem ao século XIX, quando os movimentos sociais na luta por direitos e pela igualdade principiaram tal discussão. $\mathrm{O}$ autor destaca que inicialmente esses movimentos ocorreram de forma mais expressiva em referência às diferenças de classe. Isso se deve principalmente à influência da teoria marxista, segundo a qual a partir da perspectiva da relação capital/ trabalho, o socialismo derrubaria o capitalismo (diferenças de classe) e consequentemente as outras diferenças (SANTOS, 1999; ZAMBONI, 2014).

Movimentos ligados à raça e gênero já ocorriam, porém, apenas no final do século XIX começaram a adentrar os espaços acadêmicos, gerando assim, uma gradual discussão. Essas manifestações questionaram mais fortemente a centralidade dos movimentos de classe e trouxeram debates sobre gênero, sexualidade, meio ambiente, raça, direitos dos aposentados (ZAMBONI, 2014).

Quanto ao marcador gênero, destaca-se o trabalho de Scott (1995), a qual afirma que a teorização deste marcador como categoria analítica apenas alavancou no final do século XX. Segundo a autora, os estudos na temática partem de três posições teóricas: (1) patriarcado (homem superior à mulher); (2) marxismo (produção determinando o gênero) e; (3) escolas de psicanálise (identidades de gênero e produção). As relações de gênero integram o eixo das discussões sobre diferença na perspectiva do movimento feminista, o qual busca problematizar a produção de desigualdades a partir das diferenças entre o masculino e o feminino (PISCITELLI, 2002; MENDES, 2019). No contexto organizacional, Acker (1998) sugere que 
há uma subestrutura da organização que ajuda a reproduzir divisões e desigualdades de gênero, as quais já imperam na sociedade e que privilegiam o gênero masculino.

A partir da compreensão de que as diferenças são demarcações sociais, culturalmente construídas, por meio de significações que lhes são atribuídas, a sexualidade passa a adentrar nos debates, principalmente através do movimento gay. Coloca-se em questionamento a heterossexualidade compulsória, as exigências sociais, os valores, normas e padrões morais predominantes que aparta gays, lésbicas, bissexuais e outras identidades que não seguem a norma. A discussão sobre sexualidade ascende, posteriormente, principalmente através da teoria queer, que critica a matriz de poder dominante, que vê a identidade humana como fixa, os sexos como binários e a noção dominante que estigmatiza e inferioriza lésbicas, gays, bissexuais, travestis, transexuais e transgêneros (LGBTTT) (SOUZA, 2017; POMPEU; SOUZA, 2018; MENDES, 2019).

Raça/etnia, por sua vez, é discutida principalmente a partir dos embates quanto à necessidade de dar voz à mulher negra. Esta teve sua história silenciada através da produção de discursos e de conhecimento hegemônicos contados por brancos e estudiosos de pensamento moderno ocidental dominante. Os debates a respeito de raça tratam não apenas da mulher negra, mas, problematizam os preconceitos e discriminação sofridos pelos negros e negras, inseridos em relações desiguais de poder (RIBEIRO, 2017). Um aspecto de destaque neste eixo de diferenciação consiste no processo histórico dos negros, que é marcado por intensa exploração pelos países colonizadores, e que repercute até hoje em seus espaços e posições ocupadas (RIBEIRO, 1995; ROSA, 2014).

Por fim, geração se constitui um marcador social de diferença tratado nos estudos através do termo ageísmo ou etarismo, que se refere a todo e qualquer preconceito e discriminação devido a uma determinada faixa etária. Ageísmo é uma nomenclatura criada por Butler (1969), a qual diz respeito a um processo de formação de preconceitos e estereótipos pela sociedade no que tange à idade. Essas concepções impactam também o contexto organizacional, no que se refere aos processos e práticas de contratação, inserção e permanência no mercado de trabalho (LOTH; SILVEIRA, 2014; SILVA; HELAL, 2019). O quadro 1, a seguir, expõe sinteticamente as principais informações sobre cada marcador social da diferença aqui discutido:

Quadro 1: Principais informações sobre os marcadores sociais da diferença

\begin{tabular}{|c|c|c|c|}
\hline $\begin{array}{c}\text { Marcador Social da } \\
\text { Diferença }\end{array}$ & Preconceito & Teoria & Principais autores \\
\hline
\end{tabular}




\begin{tabular}{|l|l|l|l|}
\hline Classe & Classe social & Marxismo & Karl Marx \\
\hline Gênero & Machismo & Feminismo & $\begin{array}{l}\text { Joan Scott } \\
\text { Joan Acker }\end{array}$ \\
\hline Raça/etnia & Racismo & $\begin{array}{l}\text { Stand Point } \\
\text { Black Feminist Thought }\end{array}$ & $\begin{array}{l}\text { Patricia Hill Collins } \\
\text { Kimberlé Crenshaw }\end{array}$ \\
\hline Sexualidade & Heterossexismo & Teoria Queer & Judith Butler \\
\hline Geração & Ageísmo ou etarismo & Ageísmo & Robert Butler \\
\hline
\end{tabular}

Fonte: Elaborado pelas autoras (2020).

Essas contextualizações demonstram, como ressaltado por Brah (2006), que as discussões muitas vezes têm se voltado a uma ou outra categoria de distinção social exclusivamente. Sendo necessário problematizar as estruturas de classe, raça/etnia, gênero, sexualidade, geração como elementos interdependentes e interseccionados, pois a opressão de cada uma está inscrita na outra, sendo formada pela outra e constituindo-a (BRAH, 2006; SOUZA, 2014; ZAMBONI, 2014), o que será explorado com maior afinco no item seguinte.

\subsection{INTERSECCIONALIDADE: HISTÓRICO, CONCEITO E IMPORTÂNCIA}

O debate acerca da interseccionalidade teve início nos movimentos feministas, mais precisamente por volta de 1982 com o manifesto chamado A Black Feminist Statement, que teve como proposta abarcar, de maneira interconectada, os múltiplos sistemas de opressão que mulheres negras sofrem. Esta discussão partiu da intenção de compreender que gênero, raça, classe e sexualidade moldam a experiência da mulher negra, que essas desigualdades sociais complexas devem ser trabalhadas por meio de uma agenda de justiça social e que as interseções devem ser vistas como ideias e ações (HIRATA, 2014; HENNING, 2015; COLLINS, 2017).

Os movimentos sociais defendiam uma luta articulada na qual o interesse se voltava contra a opressão sexual das mulheres e as outras formas de dominação e de desigualdades relacionadas ao racismo, heterossexismos e exploração por classe social (HENNING, 2015). Pontua-se também que a preocupação feminista com as formas de entrelaçamento de diferenças não estava somente associada às mulheres negras, mas às latinas, indígenas e asiáticas que desempenharam um importante papel na reivindicação da inter-relação de raça, classe, gênero e sexualidade nos movimentos sociais (COLLINS, 2017). Assim, estes temas emergiram pela primeira vez nos estudos de mulheres, que pleitearam seus direitos na busca para incluir nos discursos hegemônicos as suas experiências, apresentaram críticas acerca da estabilidade 
homogeneizante da categoria mulher e buscaram mostrar a necessidade de se atentar de forma igualitária às diversas formas combinadas de diferenças e desigualdades (HENNING, 2015; COLLINS, 2017).

A articulação dessas mulheres trouxe a discussão da interseccionalidade para diferentes espaços sociais, incluindo o contexto acadêmico, na tentativa de abranger nos discursos hegemônicos da academia o feminismo negro, o qual ficou inicialmente como um projeto de justiça social (HENNING, 2015; COLLINS, 2017). Gradualmente, a interseccionalidade ganhou força nos limites entre o espaço acadêmico e os movimentos sociais (COLLINS, 2017), ao buscar fazer uma crítica ao essencialismo contido na categoria mulheres (BRAH, 2006; HENNING, 2015) e ao abordar a interseccionalidade para analisar classe, raça, gênero e sexualidade de maneira interconectada (COLLINS, 2017). É relevante frisar também que à medida em que as ideias relacionadas aos estudos de classe, raça e gênero ganharam espaço na academia, foram se afastando dos movimentos sociais (COLLINS, 2017).

Vale salientar que a emergência da interseccionalidade, no contexto acadêmico, é delegada a Kimberlé Crenshaw que estabeleceu em seu artigo o uso deste termo para mapear as margens da política de identidade e violência doméstica contra mulheres de cor (COLLINS, 2017) e trouxe a preocupação em entrelaçar diversas maneiras de diferenciações sociais (HENNING, 2015). A teórica "foi posicionada na convergência dos estudos de raça/ classe/ gênero na academia, assim como na centralidade de iniciativas de justiça social para as mudanças legais e sociais que fizeram avançar argumentos da interseccionalidade" (COLLINS, 2017, p.10). Logo, as pesquisas de Kimberlé Crenshaw contribuíram com uma visão mais abrangente acerca do desenvolvimento da interseccionalidade como projeto de conhecimento.

Os estudos a respeito das ideias de interseccionalidade, por volta do século XXI, ganharam um vasto interesse no campo das ciências sociais e várias disciplinas passaram a trabalhar os estudos da mulher, levando a articulação das percepções interseccionais a sério. Este envolvimento interdisciplinar contribuiu também nos campos voltados às políticas e à saúde pública que mostraram afinidade para abordar os contextos de suas áreas a partir de perspectivas interseccionais (COLLINS, 2017).

Deste modo, a interseccionalidade é entendida por Crenshaw (2002, p. 177) como sendo uma forma de conceituar um problema para capturar as consequências entre dois ou mais eixos da subordinação. Ela visa tratar "da forma pela qual o racismo, o patriarcalismo, a opressão de classe e outros sistemas discriminatórios criam desigualdades básicas que estruturam as posições relativas de mulheres, raças, etnias, classe e outros”. Esses vários eixos evidenciam hierarquias de poder distintas que estruturam os terrenos sociais, econômicos e políticos e criam (c) $($ () $\Theta$ REAd | Porto Alegre - Vol. 26 - N. 3 - Setembro / Dezembro 2020 - p. 819-850. 
intersecções complexas que possibilitam que dois ou mais eixos se entrecruzem e gerem múltiplas e simultâneas opressões.

Piscitelli (2008) coaduna com essas afirmações ao colocar que as interações entre as diferentes formas de subordinação permitem um nivelamento de opressões ao passo que possibilitam tratar como as ações políticas geram opressões ao longo desses eixos e constituem aspectos do desempoderamento. A autora ainda acrescenta que a interseccionalidade visa perceber a coexistência de diversas abordagens e corrobora com recursos importantes para pensar nas articulações entre raça, gênero, classe, sexualidade e compreender as experiências das mulheres.

Conforme Hirata (2014), a interseccionalidade traz uma proposta que leva em conta a apreensão de forma integrada das múltiplas fontes de identidades e desigualdades sociais ao considerar a articulação de sexo e raça para olhar as diferenças entre homens brancos e negros e mulheres brancas e negras. A percepção da autora é reforçada por Brah e Phoenix (2004), Brah (2006) e Piscitelli (2008) que pontuam a interseccionalidade como articulação de categorias, que oferece ferramentas analíticas para compreender o imbricamento de várias diferenças e desigualdades, dentre estas, Henning (2015) destaca a invisibilidade de mulheres negras nos contextos sociais.

Com base nessas constatações, Moutinho (2014) explica que os debates sobre a interseccionalidade estão envoltos das reflexões acerca das articulações dos marcadores sociais da diferença para encontrar novas fórmulas de políticas capazes de enfrentar as desigualdades. Neste caso, a interseccionalidade aponta para a necessidade de avançar em políticas emancipatórias capazes de construir uma sociedade mais justa (CRENSHAW, 2002; COLLINS, 2017).

Diante disso, é por este direcionamento que a interseccionalidade vem sendo destacada nos últimos tempos, pois tem sido vista como um dos caminhos para combater as múltiplas e simultâneas opressões, sendo, portanto, um instrumento de luta política (CRENSHAW, 2002; HIRATA, 2014). É considerada também como um projeto de conhecimento e uma arma política (COLLINS, 2017) que coloca em pauta a necessidade de pensar e analisar conjuntamente as dominações e diversas formas de opressões e graus de desigualdades. Insta salientar que apesar das diferentes abordagens no que tange à explicação e compreensão das interseccionalidades, este trabalho possui como parâmetro os estudos de Brah e Phoenix (2004) e Brah (2006). A partir desses estudos, compreende-se que a articulação das diferenças pode gerar não apenas desigualdades, mas possibilidades de resistência, além de explicitar a distinção entre diferença e desigualdade. 
Neste percurso, é indispensável acrescentar que a interseccionalidade constitui um valioso mecanismo para se analisar a produção de desigualdades de classe, gênero e raça no contexto organizacional (ACKER, 2006). Sendo assim, para que se compreenda como ocorre a interseccionalidade no âmbito organizacional, o próximo tópico deste artigo se concentra em abordar esta temática, mostrando como ela foi se firmando neste campo de estudo.

\subsection{INTERSECCIONALIDADE NO CONTEXTO ORGANIZACIONAL}

Acker (2006) argumenta que no ambiente corporativo é imprescindível buscar identificar como as instituições perpetuam desigualdades, e que mesmo nas organizações que têm objetivos igualitários explícitos, é notável a existência de regimes de desigualdades no decorrer do tempo. Mais especificamente, a autora afirma que "todas as organizações têm regimes de desigualdade, definidos como práticas pouco inter-relacionadas, procedimentos, processos, ações e significados que resultam e mantêm classe, gênero, e desigualdades raciais dentro de organizações específicas" (ACKER, 2006, p. 443, tradução nossa). São essas práticas tidas como "comuns", "naturais" e "normais", construídas pela sociedade ao longo do tempo, que são reproduzidas no espaço organizacional, e que colocam em destaque a necessidade de entender quais são os estereótipos percebidos em relação ao preconceito e discriminação constantes nas articulações dos marcadores sociais da diferença.

À vista disso, a continuação e reprodução de desigualdades podem ser melhor compreendidas por meio das cinco práticas elucidadas por Acker (2006), a saber: (1) organização dos requisitos gerais de trabalho: são diferentes entre as organizações e os níveis hierárquicos, sendo geralmente a figura representada neste ambiente o homem branco, sem responsabilidades familiares; (2) organização das hierarquias de classe: assenta-se na divisão de cargos e tarefas, tomando por base a categoria salarial, o gênero e os padrões raciais; (3) recrutamento e contratação: busca seguir um padrão determinado para definir um perfil adequado para o cargo, tendo como parâmetro o gênero e a raça dos trabalhadores; (4) fixação de salários e práticas de supervisão: relacionado aos processos de criação de hierarquia baseado em diferenças de gênero e raça, que podem reproduzir sistemas de desigualdades e diferenças entre os indivíduos, variando em diversas organizações e; (5) interações informais durante o trabalho, que está atribuído às formas com que classe, raça e desigualdades de gênero se reforçam e que, às vezes, ocorrem no contexto organizacional de maneira sutil e implícita, dificultando sua observação. 
É fundamental destacar também que há dificuldade em abordar as interseccionalidades como uma questão de curso na literatura acadêmica e na prática organizacional, inquietação evidenciada por Holvino (2010). A autora parte do argumento de que é necessário reconceitualizar as intersecções de raça/etnia, gênero, classe e sexualidade como processos simultâneos de identidade, prática institucional e social. Assim, ela expõe formas de se trabalhar essa redefinição, contribuindo com novas teorias, pesquisas e observações de práticas em estudos organizacionais.

Nesse mesmo sentido, Acker (2006) com a finalidade de gerar uma melhor compreensão a respeito da interseccionalidade, enfatiza a importância de se identificar as bases para as desigualdades no âmbito organizacional, apontando a necessidade de se considerar as articulações de classe, gênero e raça nesse contexto. Acker (2006) diz, ainda, que o termo "classe" se refere à resistência e diferenças sistemáticas no acesso e controle dos recursos para provisionamento e sobrevivência; o termo "gênero" consiste nas diferenças socialmente construídas entre homens e mulheres e nas crenças e identidades que classificam as diferenças e a desigualdade; e por fim, o termo "raça" alude às diferenças socialmente definidas com base em características físicas, cultura, dominação e opressão históricas, justificadas por crenças arraigadas. A autora enfatiza também que todos estes eixos de diferenciação estão presentes em todas as organizações.

Outro aspecto que se destaca nos trabalhos de Acker (1998; 2006) diz respeito à segregação pela qual homens e mulheres se encontram no ambiente de trabalho, implicando diretamente na visão de que existem profissões específicas para homens e para mulheres (HIRATA et al., 2009), impactando nas remunerações dos profissionais. Nota-se que no passado a diferença entre mulheres e homens serviu como justificativa para marginalizar os direitos das mulheres e, de forma mais geral, para justificar a desigualdade de gênero. Todavia, adotando outra perspectiva, observa-se que a diferença das mulheres indica a responsabilidade que qualquer instituição tem de incorporar uma análise de gênero e seus entrelaçamentos em suas práticas (CRENSHAW, 2002; ACKER, 2006).

Neste percurso, vale ressaltar outra interseccionalidade frequente no contexto organizacional, que se refere às associações entre geração e gênero. Conforme discorrem Silva e Helal (2019) mais enfaticamente sobre o fenômeno "ageísmo", porém evidenciam que é importante estudá-lo através da articulação com outras questões, como gênero, destacando que homens e mulheres possuem experiências distintas no que se refere ao trabalho. Tais experiências demonstram que a sociedade e o contexto corporativo se organizam compreendendo o trabalho como mais central para o homem do que para a mulher (ACKER, 
1998; 2006) e como mais adequado ao jovem do que ao sujeito idoso (LOTH; SILVEIRA, 2014), constituindo preconceitos interligados.

Em que pese essas considerações, é importante trazer à tona o elemento da visibilidade da desigualdade, em que a definição do grau de consciência desta varia em diferentes organizações, podendo ser intencional ou não. E como Acker (2006) argumenta, a visibilidade também depende da posição e do ponto de vista do observador, mais especificamente pessoas em grupos dominantes geralmente não se atentam à desigualdade, enquanto que os grupos dos dominados sofrem opressões múltiplas, como a invisibilidade. Esta, é sentida nas diferenças salariais, nos cargos ocupados, nos tratamentos entre líder/colaborador e colaborador/colaborador no contexto organizacional.

Acker (2006) ainda explicita a preocupação em evidenciar como as práticas organizacionais legitimam os regimes de desigualdade. Ela o faz, através de várias comparações e descrições de relações hierárquicas desiguais, como a diferença considerável entre os salários de gerentes, executivos, líderes e chefes de departamento, e de profissionais como secretários, trabalhadores de produção, estudantes ou até professores; como a definição de cargos apropriados à mulheres, que sejam diferentes dos considerados aos homens; crença na inferioridade racial e na superioridade de traços e comportamentos masculinos, entre outros. Destarte, as desigualdades são legitimadas, com frequência, por meio de argumentos normativos que naturalizam a desigualdade.

Logo, diante o exposto, é inegável constatar que esses regimes de desigualdades são práticas que inferiorizam, determinam posições assimétricas e acarretam em consequências negativas nas vivências e experiências das pessoas no contexto organizacional. Pois, elas acabam sendo marginalizadas, excluídas e negligenciadas nos processos de gestão das organizações.

\section{PROCEDIMENTOS METODOLÓGICOS}

Os procedimentos metodológicos adotados nesta pesquisa partem de uma abordagem qualitativa por meio da observação de representações de realidades e práticas desenvolvidas com a finalidade de compreender e interpretar o fenômeno em estudo (FLICK, 2009). Neste caso, o objeto de pesquisa foram as diferenças e interseccionalidades contidas no ambiente organizacional, partindo da identificação de uma lacuna a respeito da pouca quantidade de estudos nacionais que tratam destas temáticas no cenário organizacional. Diante disso, deu-se 
ênfase ao exame dos filmes por meio da leitura subversiva dos componentes não verbais e das práticas realizadas pelos personagens.

Em relação ao objetivo pretendido, a pesquisa se configura como descritiva, uma vez que se buscou analisar os marcadores sociais da diferença e interseccionalidades representados na figura do/a líder organizacional nos filmes Amor sem Escalas, O Diabo veste Prada e Um Senhor Estagiário. Além do mais, este tipo de pesquisa traz descrições que se referem a como os acontecimentos são experienciados, como também, às coisas usuais e corriqueiras que ocorrem nos contextos que estão sendo investigados (BAUER; GASKELL, 2002). Esta constatação possibilitou que as pesquisadoras pudessem analisar as performances dos principais personagens para compreender como as diferenças e as interseccionalidades são representadas nas figuras de líderes naqueles ambientes organizacionais e como produzem e reproduzem sistemas de opressões. As averiguações contribuíram para a identificação dos principais marcadores sociais da diferença, que estão permeados na organização, e no modo como eles se interseccionam, gerando regimes de desigualdades ou subvertendo os padrões considerados "normais".

No que tange às estratégias empregadas neste trabalho foi realizado um levantamento das cenas dos filmes, seguindo os critérios elencados por Bauer e Gaskell (2002), quais sejam: data, sujeitos e lugar, por entender que estes permitem às pesquisadoras assistir, sentir e buscar cenas chaves que deem suporte para apreender os temas investigados, nomeadamente, os marcadores sociais da diferença e interseccionalidades. Essas determinações ocorreram com base na análise das estruturas das cenas com a intenção de interpretar as diferenças e os padrões de interseccionalidades em todos os filmes investigados (FLICK, 2009). Assim, a operacionalização desta estratégia se deu da seguinte forma: (1) levou-se em consideração o ano de publicação dos filmes, por estes serem atuais e refletirem ações que são vividas e experienciadas no cotidiano organizacional; (2) observou-se os sujeitos, haja vista que os três filmes estão pautados na atuação de líderes organizacionais, destacando, principalmente, a atuação da mulher como líder, no qual foi possível detectar as ações de cada personagem nas cenas e mostrar as diferenças, desigualdades e interseccionalidades que estão envoltas dos cargos de liderança; (3) ponderou-se o lugar onde estes filmes são retratados, haja vista que o enredo dos filmes se passa predominantemente no contexto organizacional, culminando na identificação de ações de reforço de estereótipos, subversões do considerado normal e/ou desigualdades neste ambiente. As aferições possibilitaram situar as pesquisadoras para a realidade do cenário investigado e contribuíram para as inferências e o reconhecimento dos 
principais marcadores sociais da diferença e das interseccionalidades disponíveis em cada filme.

A técnica de coleta de dados utilizada foi a microanálise estruturada das cenas de cada filme, bem como das situações nas quais as imagens estão apoiadas e as palavras faladas gravadas em vídeo (FLICK, 2009). Esta técnica dá condições para que as pesquisadoras examinem as realidades passadas em cada filme, anotem as situações de cada contexto para que fique claro porque certas situações ou sequências de ações devem ser categorizadas de um modo específico (BAUER; GASKELL, 2002), ou seja, entender o ambiente organizacional dos filmes a partir das diferenças e interseccionalidades. Deste modo, esta técnica foi operacionalizada após a escolha dos filmes, em que as pesquisadoras os assistiram conjuntamente e em dias distintos. Durante a ocorrência dos filmes foram realizadas pausas, sempre que se mostrava necessário, para melhor entender as falas e as práticas realizadas pelos personagens. Além disso, foram feitas anotações sobre cada cena na qual se evidenciava aspectos interseccionais e/ou marcadores sociais da diferença. Ao final da exibição dos filmes, houve debates sobre os dados registrados, o que permitiu maior compreensão sobre os objetos analisados.

No que se refere à etapa de análise e interpretação dos filmes, foi realizada a triangulação de pesquisadores, dada a sobreposição de dados que possibilitou uma análise multidimensional dos fenômenos investigados e contribuiu para a eliminação de possíveis explanações equivocadas que tenham sido feitas (BAUER; GASKELL, 2002). Desse modo, o estudo contou com análises e deduções cruzadas de pesquisadores, em que cada um coloca suas posições no que tange aos achados das pesquisas (MARTINS; THEÓPHILO, 2009). O que permitiu assegurar uma maior validade e confiabilidade das interpretações submetidas às argumentações teóricas aqui trabalhadas.

Por fim, o processo analítico das informações colhidas se deu por meio da transcrição das conversas obtidas e pelo exame dos trechos dos filmes e das performances dos personagens, ponderando as entrelinhas e utilizando como categorias de análise os marcadores sociais da diferença e as interseccionalidades. Assim, as questões chaves foram retiradas a partir das realidades contidas em cada filme e interpretadas com base nos procedimentos das sequências de cada ação (FLICK, 2009).

\section{DISCUSSÕES OPORTUNIZADAS}

\subsection{MARCADORES SOCIAIS DA DIFERENÇA E INTERSECCIONALIDADES EM} AMOR SEM ESCALAS

(c) (1) $\Theta$ REAd | Porto Alegre - Vol. 26 - N. 3 - Setembro / Dezembro 2020 - p. 819-850. 
O filme Amor sem Escalas foi lançado em 2009 e ganhou o prêmio Globo de Ouro, sendo considerado o filme de melhor roteiro de cinema e o prêmio AFI, de melhor filme do ano. No campo da Administração, ele é visto como um dos mais indicados para verificar o perfil de liderança organizacional. O enredo do filme retrata a história do executivo Ryan Bingham (George Clooney) que trabalha em um escritório terceirizado, cuja função é ajudar os chefes de empresas a demitir seus colaboradores. O trabalho de Ryan se revela confortável, pois parte de sua vida se concentra em viagens pelo país e, com sua experiência pessoal e profissional em negócios, consegue harmoniosamente demitir as pessoas.

O empresário tem uma relação direta com seus patrões, sem estranhamento, até o momento da chegada da jovem Natalie Keener (Anna Kendrick), que irá trabalhar com ele nas viagens para realizar as demissões designadas pela empresa. A jovem, querendo aplicar o conhecimento que possui sobre o serviço, sugere ao chefe fazer este trabalho através da internet para economizar nas viagens.

Embora Natalie não exerça um cargo de liderança de maneira central, uma vez que divide a mesma função com Ryan, e os personagens estão subordinados a um CEO, há de se destacar que a chegada dela na organização deixa Ryan inseguro, pois a personagem possui habilidades diferentes, é jovem e mulher. Natalie se demonstra confiante, buscando inserir inovações nos processos demissionais da organização, porém se ampara em seu conhecimento, afirmando diversas vezes que se formou em uma excelente universidade norte-americana, para obter reconhecimento por parte dos outros colaboradores, o que se demonstra necessário por seu gênero (SCOTT, 1995; ACKER, 1998; PISCITELLI, 2002) e faixa etária (LOTH; SILVEIRA, 2014; SILVA; HELAL, 2019). Além disso, por subverter o considerado "normal", ocupando um espaço que seria adequado a um homem, vê seu relacionamento amoroso findar. Como tratado por Acker (1998), existe uma subestrutura que coloca o homem em posição privilegiada inclusive no contexto organizacional, no qual a mulher busca se inserir, mas não sem entraves.

A partir deste cenário, é possível observar todo o desenrolar do enredo do filme no contexto organizacional, no qual se percebe um reforço do estereótipo do homem mais velho, hétero, branco, mais experiente, e que possui mais tempo de trabalho, ocupando cargos de liderança. Dados que comprovam o perfil heteronormativo masculino e estabelece hierarquia de opressões (BRAH, 2006; MENDES, 2019), uma vez que colocam a jovem mulher, hétero, branca, como inexperiente, frágil, emotiva e que privilegia a vida pessoal em detrimento da profissional. Sendo estes fatores explicitados na cena em que a personagem Natalie sofre o fim 
do relacionamento amoroso e pede consolo a Ryan, deixando a figura feminina como dependente da masculina. Nota-se, ainda, o reforço à lógica binária (homem versus mulher), comum às matrizes de poder (BUTLER, 2003).

Pela análise, é possível apreender que o marcador social da diferença gênero é retratado no filme de forma a dividir e distinguir o masculino e feminino, expondo as características masculinas como mais apropriadas ao contexto organizacional (ACKER, 1998). Esta representação vai ao encontro do que enfatizam Bernardino-Costa (2015) e Acker (2006) sobre o fato de que as práticas de gênero nas organizações ainda continuam diante de inúmeras tentativas de apagar estas desigualdades, permeadas no contexto empresarial. Este, acoberta múltiplas realidades sociais que estão infligidas não somente por gênero, incluindo também as interseccionalidades de raça/etnia e classe.

No decorrer das cenas, também é possível inferir que os colaboradores demitidos são pessoas com baixa remuneração, de cargos de nível não elevado, em sua maioria, possuem uma idade já avançada, são supostamente héteros e o perfil de raça predominante é o branco, existindo demissão apenas de cinco negros, os quais aparecem predominantemente nas cenas de desligamento, não havendo nenhum negro entre os atores principais, exercendo efetivamente liderança. Além destes, só ocorre mais uma cena em que aparece uma mulher negra participando de uma reunião com aproximadamente quinze pessoas, sendo ela a única negra, todavia não fica evidente se ela, naquele contexto, está exercendo o papel de líder.

A partir destas cenas, verifica-se como os marcadores sociais da diferença estão imbricados na representação do ambiente organizacional, e como algumas diferenças são pouco retratadas, corroborando para a ilação de existência de discriminação e desvantagem racial, de gênero e de classe nas empresas (ACKER, 2006). Ademais, nestas cenas do filme, evidenciase a diferença de raça/etnia, demonstrando que os negros são minoria no contexto organizacional, pois não fica claro qual o papel exercido, nem tampouco o cargo ocupado por eles, depreendendo uma invisibilidade na conjuntura organizacional (ROSA, 2014; RIBEIRO, 2017). À vista disso, examina-se que os fatores gênero, geração e raça/etnia podem ocasionar diferentes impactos na organização.

No caso do filme, é apreendido que o preconceito por idade está no personagem Ryan, que tenta de diversas maneiras "testar" o conhecimento de Natalie por acreditar que o fato de ela ser mais jovem e mulher causa limitação para lidar com as tarefas de gerenciamento da empresa e condução de atividades, por a mesma não possuir longa experiência profissional em comparação a ele. Ao mesmo tempo, a jovem também expressa sentimentos de preconceito ao 
subestimar a forma como a geração de Ryan articula as atividades, sem necessitar de muita inovação e tecnologia.

Pelos relatos explanados acima, é plausível dizer que este tipo de discriminação ligado à faixa etária ocorre tanto do idoso para com o jovem como o contrário, pois enquanto os jovens criam estereótipos em relação ao baixo desempenho dos mais idosos, estes, por sua vez, acrescentam que o senso de pertencimento à empresa é mais evidente nos mais velhos. Deste modo, estas duas classes de trabalhadores se estereotipam e percebem algumas características positivas e outras negativas que podem ser ameaçadoras na competição por espaços organizacionais (LOTH; SILVEIRA, 2014; SILVA; HELAL, 2019).

O reforço de estereótipos é visto nos diálogos e atitudes de Ryan e Natalie no decorrer do filme, quando ambos buscam se sobressair como líder: enquanto ele enfatiza sua experiência profissional, praticidade e racionalidade como inerentes à figura masculina, ela demonstra ideias inovadoras associadas à tecnologia, característica atribuída ao jovem. Como salientado por Acker (2006) e Holvino (2010), os próprios colaboradores acabam por legitimar essas práticas discriminatórias, reforçando estereótipos quanto à classe, gênero e raça como processos simultâneos de identidade. As assimetrias de poder parecem estar incorporadas em todos os sujeitos, dos mais jovens aos mais idosos, reforçando a noção de poder foucaultiana, apresentada no referencial teórico deste trabalho.

A articulação dos marcadores sociais aparece também quando há o cruzamento das experiências do senhor Ryan com a jovem Natalie, em que estes personagens no final do filme revelam ter aprendido um com o outro e firmam uma relação de amizade. A imbricação destas duas gerações ocasiona interações entre os diferentes perfis etários dos trabalhadores os quais se complementam e geram efeitos positivos (LOTH; SILVEIRA, 2014). Neste relacionamento interpessoal retratado no filme, também é possível identificar subversão no ambiente organizacional, pois nos momentos das demissões, ele preza mais pelo emocional, buscando se colocar no lugar do outro. Enquanto que a jovem racionaliza mais o processo. Assim, os personagens subvertem, mesmo que pouco, a ordem e o agir considerado "normal" (ACKER, 1998; 2006).

Cabe destacar ainda que o filme em questão apresenta um contexto organizacional com algumas interseccionalidades, em que o papel do líder é ocupado, principalmente por homens brancos com vasta experiência no mercado, fortalecendo o padrão heteronormativo masculino (POMPEU; SOUZA, 2019) e ao mesmo tempo, apresenta subversões do "normal", ao depositar confiança em uma mulher jovem com conhecimentos teóricos, porém com pouca prática de trabalho, quebrando paradigmas (MENDES, 2019; POMPEU; SOUZA, 2019). 


\subsection{MARCADORES SOCIAIS DA DIFERENÇA E INTERSECCIONALIDADES EM O DIABO VESTE PRADA}

O filme O Diabo Veste Prada foi lançado no ano de 2006, e é baseado em um livro com o mesmo nome, da autora Lauren Weisberger. $\mathrm{O}$ mesmo se destaca por algumas indicações e premiações recebidas: Globo de Ouro, MTV Movie Awards, Bafta (Indicações: melhor atriz Meryl Streep, melhor atriz coadjuvante - Emily Blunt, melhor roteiro adaptado, melhor figurino, melhor maquiagem), Oscar (Indicações: melhor atriz - Meryl Streep, melhor Figurino). O enredo conta a história de uma jovem chamada Andrea Sachs (Anne Hathaway) que almeja uma oportunidade para deslanchar na carreira de jornalista. Para tanto, decide trabalhar em uma renomada revista de moda, a Runway, que conta com Miranda Priestly (Meryl Streep) como principal executiva. Pontua-se ainda, que este filme é um dos mais citados na área de Administração, sendo o mesmo comumente trabalhado em disciplinas sobre liderança.

O filme retrata um contexto organizacional no qual a figura da líder é representada por uma personagem do gênero feminino, qual seja, Miranda Priestly, de idade média, branca, heterossexual, de classe social alta, sendo estes os marcadores sociais da diferença nítidos no filme (ACKER, 2006; BRAH, 2006; ZAMBONI, 2014; SAGGESE et al., 2018; HIRANO; ACUÑA; MACHADO, 2019). Ela é considerada uma excelente profissional do ramo da moda, altamente respeitada e até mesmo temida por seus colaboradores, o que se deduz pelo fato de atuar como gestora seguindo os padrões de comportamento considerados masculinos, ao priorizar a carreira profissional em detrimento da família, não firmando relacionamentos amorosos duradouros, nem tampouco uma relação afetuosa com suas filhas. Esta postura de exercer comportamentos considerados masculinos é frequentemente utilizada por mulheres no contexto organizacional, reforçando os estereótipos de que características tidas como inerentes ao homem são mais adequadas ao ambiente empresarial (ACKER, 1998, 2006; PISCITELLI, 2002; MENDES, 2019).

Além disso, pode-se perceber que Andrea, embora não exercendo a função de líder, ao adentrar este espaço também vivencia uma situação conflituosa entre profissão e vida pessoal, ao ser questionada algumas vezes por seu namorado, pai e amigos sobre sua dedicação à carreira profissional. Neste impasse, nas cenas finais do filme, a personagem opta por não priorizar o trabalho em detrimento da vivência familiar e amizades. Ressalta-se e infere-se, assim, as divisões e desigualdades, do marcador social da diferença gênero, produzida na sociedade e reproduzidas no contexto organizacional, que privilegia o homem (ACKER, 1998).

(c) (1) $\Theta$ REAd | Porto Alegre - Vol. 26 - N. 3 - Setembro / Dezembro 2020 - p. 819-850. 
Outro aspecto que se destaca no filme consiste na predominância do elenco feminino, havendo apenas um homem em contato direto com a gestora, reforçando o estereótipo de que na área da moda é mais comum haver mulheres do que homens envolvidos no negócio. Coadunam com esta assimilação, as afirmações de Acker (1998; 2006) e Hirata et al. (2009) ao tratarem sobre as relações sociais de gênero, enfatizando que as divisões de trabalho definem profissões específicas para homens e mulheres, as quais podem interferir em remuneração e ascensão profissional. De acordo com Hirata et al. (2009), esta segregação laboral tem dois princípios organizadores: o da separação (existem atividades/trabalhos de homens e outros de mulheres) e o da hierarquização (o trabalho de um homem vale mais do que o trabalho de uma mulher).

Cabe apontar também a impressão de que o perfil de Miranda enquanto gestora reforça algumas características que estão ligadas ao marcador geracional (LOTH; SILVEIRA, 2014; SILVA; HELAL, 2019), pois a mesma possui ampla experiência no ramo de moda, é extremamente dedicada à empresa e não está envolvida com as tecnologias para trabalhar com as novas edições, uma vez que prefere trabalhar manualmente, solicitando diariamente às suas auxiliares "o livro" que contém as novidades da moda. Tais aspectos se constituem no reforço dos estereótipos referentes ao sujeito idoso, o que é percebido no filme, também, quando Miranda é cogitada para ser substituída por uma profissional da moda mais jovem que ela, Jacqueline Follet (Stéphanie Szostak).

No que concerne ao marcador "classe", verifica-se ainda, na cena supracitada em que Jacqueline é promovida pelo fato de ter uma posição social superior a de Nigel (Stanley Tucci), mesmo sendo ele um dos colaboradores mais empenhado e dedicado. Esta situação corrobora com o posicionamento de Zamboni (2014), o qual aborda que as categorias de classificação social estão relacionadas a uma determinada posição hierárquica que tende a privilegiar uns e excluir outros, podendo esse marcador se referir a ricos e pobres, classe média e proletariado, profissionais liberais e moradores de rua.

Outros marcadores sociais apreendidos no filme são raça e gênero, em que há o predomínio de personagens de cor branca e do gênero feminino, por se tratar do ramo de moda. No cenário analisado, é possível perceber apenas um personagem homem e negro, o famoso designer de moda James Holt (Daniel Sunjata), interagindo com a empresa que Miranda dirige. Aqui, nota-se interseccionalidade referente ao gênero (um dos poucos homens relacionados à moda no filme) e à raça (único homem negro com papel de destaque) subvertendo os padrões considerados normais (GOFFMAN, 1963; BRAH, 2006). Em relação ao marcador "sexualidade", inferiu-se que o padrão heteronormativo (BUTLER, 2003; MENDES, 2019; 
POMPEU; SOUZA, 2019) foi mantido de maneira preponderante no filme, exibindo apenas casais heterossexuais, havendo a ausência de casais ou mesmo personagens solteiros ou declaradamente LGBTTT.

Pela análise do filme $O$ Diabo veste Prada, depreende-se fortemente as interconexões entre os marcadores sociais da diferença classe, gênero, geração, raça e sexualidade, constandose que no ambiente organizacional há o reforço dos estereótipos que produzem e reproduzem desigualdades e relações sociais hierárquicas e assimétricas.

\subsection{MARCADORES SOCIAIS DA DIFERENÇA E INTERSECCIONALIDADES EM UM SENHOR ESTAGIÁRIO}

O filme Um Senhor Estagiário foi lançado no ano de 2015 e recebeu algumas indicações: Teen Choice Award (melhor atriz - Anne Hathaway, melhor ator - Robert De Niro e melhor filme de comédia). Esta obra cinematográfica retrata a história de Ben Whittaker (Robert De Niro), um viúvo com idade de 70 anos, aposentado, que ao descobrir uma oportunidade de trabalho, busca se inserir novamente no ambiente corporativo. Um senhor estagiário narra a experiência de inserção deste personagem, o qual galga um cargo de estagiário sênior em uma empresa que opera um site de moda, socializando com a diretora e fundadora da organização, Jules Ostin (Anne Hathaway) e demais colaboradores. Vale ressaltar que o filme é muito abordado na área de ensino da Administração, sendo utilizado e recomendado em discussões que envolvam a temática de liderança.

O personagem Ben é um executivo inativo, que no início do filme, demonstra-se bastante impactado com a aposentadoria, descrevendo sentimentos de vazio, inutilidade e invisibilidade perante a sociedade. A partir disso, busca realizar atividades no esforço de obter novamente o sentimento de pertencimento, o que pode ser exemplificado através da cena em que Ben procura frequentar um "café", o qual geralmente recebe executivos. Apesar de estar entre os executivos, compartilhando a mesma mesa, estes não lhe dirigem o olhar, nem tampouco o incluem nas discussões. Como apontado por Silva e Helal (2019) a saída do mercado de trabalho configura uma perda de vínculos sociais e ruptura considerável na vida do indivíduo, e a sociedade, ao mesmo tempo em que considera o trabalho como aspecto central da vida, exclui o sujeito idoso, destinando-o à aposentadoria.

Assim, é evidenciada nesta cena da cafeteria, a diferença ligada à geração, na qual predominam alguns preconceitos de acordo com a faixa etária dos indivíduos (BUTLER, 1969) e que reverbera no contexto organizacional. Como tratado por Loth e Silveira (2014) e Silva e (c) (1) $\Theta$ REAd | Porto Alegre - Vol. 26 - N. 3 - Setembro / Dezembro 2020 - p. 819-850. 
Helal (2019), o sujeito idoso geralmente não é uma opção de contratação e de permanência no trabalho, sendo, muitas vezes, subestimado e invisibilizado neste ambiente.

Outro aspecto observado no filme, diz respeito ao estranhamento para com as tecnologias, por parte de Ben, que na cena em que confecciona um vídeo para se candidatar à vaga de estagiário sênior, relata ter solicitado ao neto auxílio para compreender alguns fatores sobre a gravação. Esse estranhamento também acontece na organização na qual ele passa a trabalhar, em que os jovens colegas o auxiliam a operacionalizar o notebook, e até mesmo a ingressar nas redes sociais, porém, ele se defende ao afirmar que aprende rápido, demonstrandose aberto aos ensinamentos e subvertendo os estigmas de que o idoso é lento e resistente ao novo. Tais elementos compõem o que Loth e Silveira (2014) chamam de estereótipos negativos em relação ao sujeito idoso, quais sejam acompanhamento da tecnologia computacional e resistência às mudanças.

A personagem Jules é uma jovem empresária do ramo de moda, que alcançou o sucesso profissional rapidamente (18 meses), contando com mais de 200 colaboradores neste curto espaço de tempo. A líder organizacional é casada, tem uma filha, e como explicitado, vivencia momentos de conflitos entre a vida pessoal e profissional, como a maioria das mulheres inseridas no mercado de trabalho, conforme aponta Acker (1998; 2006). Além disso, a relação familiar demonstrada no filme permite visualizar aspectos subversivos no que tange ao que se tem como padrão quanto aos espaços e papéis sociais de homens e mulheres, uma vez que o ambiente organizacional pensado para o homem, é ocupado por uma mulher, enquanto o homem passa a cuidar do lar, sendo definido no filme como "pai que fica em casa". Este cenário permite a apreensão de que a mulher cada vez mais passa a ocupar o mercado de trabalho, conforme destacam autoras e autores como Hirata (2014) e Henning (2015).

Nota-se que a diferença ligada a gênero é tratada no filme de forma a perturbar o que se tem por "normal" nas relações entre o masculino e o feminino (SCOTT, 1995; PISCITELLI, 2002; MENDES, 2019) em que a mulher trabalha fora e o homem cuida das atividades domésticas, mas não sem entraves, uma vez que o filme revela que o esposo de Jules por se sentir menosprezado e inferior, a trai. Ela, por sua vez, o perdoa por ter o sentimento de culpa por estar sempre trabalhando. Isso possibilita inferir que as ordens e padrões construídos pela sociedade constituem uma subestrutura que impacta o contexto organizacional, privilegiando o gênero masculino (ACKER, 1998).

Apesar de ser uma mulher moderna, Jules, assim como a maioria dos jovens trabalhadores de sua empresa, apresentam preconceitos em relação a Ben. Corroboram nessa perspectiva Loth e Silveira (2014), que pontuam que no que tange a estereótipos negativos, os (c) (1) $(9)$ REAd | Porto Alegre - Vol. 26 - ․ㅡ 3 - Setembro / Dezembro 2020 - p. 819-850. 
empregadores são mais preconceituosos em comparação com os próprios idosos. Estes, no contexto organizacional, são compreendidos como incompetentes a novos aprendizados e são excluídos de novos treinamentos, limitando o campo de possibilidades desse sujeito (LOTH; SILVEIRA, 2014; SILVA; HELAL, 2019). É possível visualizar que este cenário é proeminente no início do filme, em que Jules não quer Ben próximo de suas atividades, o que se modifica no decorrer da narrativa, de modo que Ben passa a surpreender a líder e os jovens colaboradores diversas vezes, tendo suas expectativas (baseadas em estereótipos) contrariadas, permitindo mitigar preconceitos.

Como argumentam Loth e Silveira (2014), os choques entre as gerações constituem trocas e possibilidades de aprendizagem entre as diferentes faixas etárias, pois a segregação desses atores no ambiente organizacional gera o fortalecimento de estereótipos. Ou seja, esse cenário explicita os discursos sobre definindo os discursos de, produzindo e reproduzindo desigualdades (PETRI, 2009).

É possível depreender também que os homens e as mulheres podem ter experiências de vida e de trabalho diferentes, as quais produzem consequências no tocante aos processos de tomada de decisão e de aposentadoria. Ben expõe possuir uma experiência de aproximadamente quarenta anos em uma empresa, enquanto a mulher de mesma idade possivelmente possuirá menos tempo de experiência devido à dedicação ao lar e à família. Desse modo, a matriz dominante definida e construída socialmente compreende que o trabalho está mais associado aos homens do que às mulheres (ACKER, 1998, 2006; HOLVINO, 2010; BERNARDINOCOSTA, 2015). Portanto, gênero e geração estão entrelaçados constituindo um processo de preconceitos conjugados (SILVA; HELAL, 2019).

Ademais, como explorado por Loth e Silveira (2014), o envelhecimento deve ser analisado como um processo que constitui a vida das pessoas e está interligado com outras construções sociais, como a da classe social. No filme em tela, percebe-se que a chefe e os colaboradores modificam seus conceitos em relação ao sujeito idoso no contexto laborativo; contudo, insta considerar que Ben, por ser um executivo aposentado, provavelmente teve o privilégio de estar em uma classe social que lhe permitiu voltar a se inserir no mercado de trabalho. Este retorno acontece em um cargo, posição e empresa que possibilitam determinados recursos e oportunidades que seriam, presumivelmente, negados a um idoso de classe inferior, inferindo-se um complexo entrelaçamento entre classe e geração, ao que Butler (1969) denomina de segregação de idosos. Acker (2006) complementa afirmando que as desigualdades de classe imbricadas às demais diferenças são produzidas e reproduzidas nas organizações, nas 
formas como elas empregam, como ordenam os seus processos, como estabelecem posições hierárquicas e como pagam os salários.

Verifica-se ainda, que o filme apresenta um ambiente organizacional formado predominantemente por trabalhadores jovens (empresa de moda pautada em tecnologia), sendo a maioria principalmente composta por homens, brancos, aparecendo poucos negros, os quais não compõem participação direta na narrativa empreendida. Soma-se a isso, o fato de homossexuais também não serem retratados de forma límpida no filme, explicitando os padrões da heteronormatividade masculina (POMPEU; SOUZA, 2019). Estes elementos trazem à tona os argumentos trabalhados por Acker (2006) e Mendes (2019), os quais falam que os marcadores sociais da diferença raça/etnia e sexualidade tendem a ser invisibilizados nos estudos sobre organizações e gestão, o que reverbera na representação do ambiente corporativo na ficção.

\section{CONSIDERAÇÕES FINAIS}

Realizadas as discussões acerca dos temas diferenças e interseccionalidades no contexto organizacional nos filmes Amor sem Escalas, O Diabo veste Prada e Um Senhor Estagiário, é permitido compreender que os marcadores sociais da diferença (gênero, geração, sexualidade, raça/etnia e classe) e as relações de poder que as constituem e produzem os indivíduos, através dos possíveis entrelaçamentos. A partir desta constatação, verifica-se que tais articulações produzem e reproduzem desigualdades nos diversos âmbitos da sociedade, sendo fundamental buscar compreender como elas acontecem ambiente organizacional.

À luz do que foi explorado nesta pesquisa, buscou-se por meio de associações com a teoria, analisar filmes que retratassem líderes no ambiente corporativo e suas relações interpessoais. Desse modo, a finalidade do estudo consistiu em analisar como os marcadores sociais da diferença e as interseccionalidades são representadas na figura do/a líder organizacional nos filmes Amor sem Escalas, O Diabo veste Prada e Um Senhor Estagiário.

Respaldadas neste discurso, examinou-se por meio dos marcadores sociais das diferenças, as interseccionalidades contidas no âmbito organizacional ao considerar os três filmes supracitados, no qual foi possível identificar a presença de marcadores de classe, gênero, raça, sexualidade e geração. Assim, com base na análise do filme Amor Sem Escalas entendeuse que a relação profissional entre os personagens de Ryan Bigham e Natalie Keener reforça os marcadores sociais da diferença "gênero" e "geração", pois eles criam estereótipos que podem 
corroborar para a existência de preconceitos e desigualdades. Simultaneamente, o cruzamento destes marcadores provoca diversos impactos na organização, dando possibilidades de existir a complementaridade dos diferentes perfis etários dos colaboradores.

Na análise do filme O Diabo Veste Prada, assimilou-se que os marcadores sociais da diferença mais prevalecentes no contexto organizacional exposto são "classe", "gênero", "geração" e "raça". Estes, por sua vez, revelam e reforçam o padrão de liderança heterossexual (sexualidade), branco (raça), classe média alta (classe) e jovem (geração). Este reforço parece importante no sentido de reproduzir processos de preconceitos e desigualdades conjugados àqueles sujeitos que não seguem o padrão. À vista desta situação pode-se entender que estas articulações são vivenciadas no cotidiano das organizações, acontecendo, às vezes, de forma tão sutil e silenciosa, que não é permitido captá-las, tal como Foucault (1979) caracteriza o poder.

O diagnóstico do filme Um Senhor Estagiário, possibilitou a identificação dos marcadores sociais da diferença a respeito de "gênero", "classe" e "geração", ocasionando o entendimento do quanto os estereótipos estão arraigados no ambiente corporativo. Pelo exame do filme foram comprovadas várias desconstruções acontecendo na empresa no que tange a expectativas etárias, apresentando subversões ao inverter o padrão familiar de papéis definidos para homem e mulher, além de, permitir inferir que as imbricações geração, classe e gênero configuram um processo de preconceitos interligados.

Partindo destas explanações, percebeu-se, ainda, que no que se refere aos marcadores sociais da diferença "raça/etnia" e "sexualidade", nos três filmes em tela não há participação representativa de pessoas não brancas e não heterossexuais. Além disso, nenhum dos filmes explora possibilidades de líderes que não atendam às lógicas binárias que constituem as matrizes de poder que sustentam as relações de gênero, sexualidade (BUTLER, 2003), raça, classe etc. Sendo assim, a ficção constitui uma imitação e representação da realidade, em que indivíduos que não atendem ao padrão, subvertendo as lógicas binárias, são invisibilizados, e as práticas organizacionais legitimadas e perpetuadas por líderes e demais colaboradores que reforçam os padrões normativos através de relações hierárquicas e desiguais.

É essencial explicitar que existem outros marcadores sociais da diferença constituintes das interseccionalidades, os quais não foram foco deste estudo, a exemplo de condição do corpo (MELLO, 2016) e nacionalidade (HOLVINO, 2010). Estes, respectivamente, compreendem as pessoas com deficiência (PcD) e sem deficiência e os grupos de diferentes nações. Tais eixos de diferenciação destacam mais questões a serem estudadas, em que outras implicações dessas 
complexas articulações permitam reconceitualizar as interseccionalidades no contexto organizacional.

Quanto às limitações desta pesquisa, evidencia-se que os produtos fílmicos constroem versões da realidade e espectadores interpretam por si mesmos, o que se tentou atenuar através da triangulação de pesquisadores. Ao mesmo tempo, os autores de ficção utilizam seus conhecimentos e vivências que experienciam em sociedade, o que permite retratar reviravoltas, tornar o familiar estranho e influenciar para novos olhares em relação ao mundo. Através da representação em filme, é possível reproduzir ou contestar normas referentes aos marcadores sociais da diferença e interseccionalidades.

Ademais, salienta-se que os filmes escolhidos retratam especificamente o contexto organizacional estadunidense, no qual se verifica fortemente o individualismo e a meritocracia na carreira profissional. Devido a esses aspectos, supõe-se: há a possibilidade de inversão dos padrões e papéis considerados adequados a cada gênero, em que nos três filmes a liderança é exercida por mulheres, subvertendo algumas "normalidades". Percebeu-se também penalidades a estas, como traição e relacionamentos não duradouros por elas se desviarem do considerado "normal" e "adequado". Essas argumentações revelam a importância de se atentar aos marcadores sociais da diferença e às interseccionalidades no ambiente organizacional para que se possa compreender as dinâmicas que acontecem em cada realidade analisada.

É interessante ressaltar que este olhar atento às diferentes e múltiplas formas de opressão desafiam as organizações a transformarem seus modelos de gestão para que estes passem também a valorizar a voz das pessoas que ocupam posições inferiores - e que são, muitas vezes, marcadas pelos estereótipos arraigados no ambiente corporativo - ou daquelas pessoas que não seguem os padrões de uma "boa" liderança. Assim, propõe-se pesquisas e análises fílmicas que descrevam outros contextos organizacionais, como no Brasil, marcado historicamente por uma formação inicial em que imperavam o trabalho escravo e a servidão, estabelecendo uma colonialidade do poder, fixando lugares e papéis sociais de homens e mulheres brancos (as), negros (as) e indígenas.

Estes aspectos podem permitir deduzir diferentes modos, características de produção e reprodução de desigualdades, como também, outras resistências. Pontua-se, desse modo, a relevância de fazer pesquisas teórico-empíricas no âmbito organizacional brasileiro sob a ótica da análise interseccional, demonstrando esta abordagem nas performances dos indivíduos e das organizações, atentando para as complexas imbricações que ocorrem entre os diversos sistemas de opressões e outras possíveis inferências específicas a esse contexto. 
Por fim, pode-se concluir que as interseccionalidades abordadas neste artigo aproximam o contexto organizacional fictício, representado nos filmes investigados, da realidade de muitas organizações, em que se reforçam os padrões normativos através de relações hierárquicas e desiguais. Estas são resultantes do cruzamento dos marcadores sociais da diferença (classe, gênero, raça/etnia, sexualidade e geração), depreendendo um processo de preconceitos interligados, que ocorrem, muitas vezes, de forma discreta e sutil na vivência do cotidiano organizacional. Estes achados corroboram para investigação de como os marcadores sociais da diferença e as interseccionalidades interferem nestes ambientes, exprimindo a oportunidade de adotar o cinema como mecanismo didático que pode servir de base de discussão, análise e críticas para se estudar outros contextos e realidades distintas.

\section{REFERÊNCIAS}

ACKER, J. The Future of 'Gender and Organizations': Connections and Boundaries. Gender, Work and organization, v. 5, n. 4, p. 195-206, 1998.

BAUER, M. W.; GASKELL, G. Pesquisa Qualitativa com Texto, Imagem e Som: um Manual Prático. Petrópolis: Vozes, 2002.

BERNARDINO-COSTA, J. Decolonialidade e interseccionalidade emancipadora: a organização política das trabalhadoras domésticas no Brasil. Revista Sociedade e Estado, v. 30, n. 1, p. 147-163, 2015.

BRAH, A. Diferença, diversidade, diferenciação. In: Cartographies of Diaspora:

Contesting Indentities. Longon/New York, Routledge, 1996. Publicado por Cadernos Pagu, 2006.

BRAH, A.; PHOENIX, A. “Ain't I a Woman? Revisting Intersectionality. Journal of International Women's Studies, v. 5, n. 3, may., p.75-86, 2004.

BUTLER, R. N. Age-ism: another form of bigotry. The Gerontologist, v. 9, n. 4, p. 243-246, 1969.

BUTLER, J. P. Problemas de gênero: feminismo e subversão da identidade. Rio de Janeiro: Civilização Brasileira, 2003.

COLLINS, P. H. Se perdeu na tradução? Feminismo negro, interseccionalidade e política emancipatória. Revista Parágrafo, v. 5, n. 1, 2017.

CRENSHAW, K. Documento para o Encontro de Especialistas em Aspectos da Discriminação Racial Relativos ao Gênero. Revista Estudos Feministas, Ano 10, 2002.

ECCEL, C. S.; GRISCI, C. L. I. Trabalho e Gênero: a produção de masculinidades na perspectiva de homens e mulheres. Cadernos EBAPE.BR, v. 9, n. 1, artigo 4, p. 57-78, 2011. 
FLICK, U. Desenho da Pesquisa qualitativa. Porto Alegre: Artmed, 2009.

FOUCAULT, M. Microfísica do poder. Rio de Janeiro: Graal. 1979.

GOFFMAN, E. Estigma: Notas sobre a manipulação da identidade deteriorada. $4^{\mathrm{a}}$ edição. LTC, 1963.

HELAL, D. Gerações e trabalho: debate à brasileira. Caruaru: Armazém da Criatividade, 2019. [Palestra da disciplina de Tópicos Especiais em Organizações: Diferenças,

Interseccionalidades e Resistências, Mestrado em Gestão, Inovação e Consumo em: 13 nov. 2019].

HENNING, C. E. Interseccionalidade e pensamento feminista: As contribuições históricas e os debates contemporâneos acerca do entrelaçamento de marcadores sociais da diferença.

Mediações, v. 20, n.2, p. 97-128, 2015.

HIRANO, L. F. K; ACUÑA, M.; MACHADO, B. F. Marcadores sociais das diferenças: fluxos, trânsitos e intersecções. Goiânia: Imprensa Universitária, 2019.

HIRATA, H. Gênero, Classe e Raça: Interseccionalidade e consubstancialidade das relações sociais. Tempo Social, revista de sociologia da USP, v. 26, n. 1, p. 61-73, 2014.

HIRATA, H.; et al. Dicionário crítico do feminismo. Editora: Unesp, 2009.

HOLVINO, E. Intersections: The simultaneity of race, gender and class in organization studies. Gender, Work and Organization, v. 17, n. 3, p. 248-277, 2010.

LIMA, T. A. P. Precisa-se de um administrador mais experiente? Métodos e Pesquisa em Administração - MEPAD, v. 2, n. 1, p. 25-32, 2017.

LOPES, A. A. D.; SILVA, A. G. C.; HELAL, D. H. E a Carreira? Voou pelos Ares!?. In: V EnEPQ - Encontro de Ensino e Pesquisa em Administração e Contabilidade, 2015, Salvador. V EnEPQ - Encontro de Ensino e Pesquisa em Administração e Contabilidade. Curitiba: ANPAD, 2015. p. 1-16.

LOTH, G.; SILVEIRA, N. Etarismo nas organizações: um estudo dos estereótipos em trabalhadores envelhecentes. Revista de Ciências da Administração, v. 16, n. 39, p. 65-82, 2014.

MACIEL, H. W. P.; HELAL, D. H. "Detalhes de sua incompetência não me interessam": o assédio moral no filme o diabo veste prada. Revista Eletrônica de Administração - REAd, v. 23, n. especial, p. 412-427, dez. 2017.

MELLO, A. G. Deficiência, incapacidade e vulnerabilidade: do capacitismo ou a preeminência capacitista e biomédica do Comitê de Ética em Pesquisa da UFSC. Ciência e Saúde Coletiva, v. 21, n 10, p. 3265-3276, 2016.

PHILLIPS, M.; KNOWLES, D. Performance and Performativity: Undoing Fictions of Women 
Business Owners. Gender, Work and Organization, v. 19, n. 4, p. 416-437, 2012.

MARTINS, G. A.; THEÓPHILO, C. R. Metodologia da investigação científica para ciências sociais aplicadas. 2. ed. São Paulo: Atlas, 2009.

MENDES, D. C. Ser ou não parecer no curso de administração? Eis a questão! A performance de alunos gays e bissexuais no contexto de um curso heteronormativo. (Tese de doutorado). Universidade Federal de Pernambuco, Recife, Brasil, 2019.

MOUTINHO, L. Diferenças e desigualdades negociadas: raça, sexualidade e gênero em produções acadêmicas recentes. Cadernos Pagu, n.42, p.201-248, 2014.

NETO, H. L. C. Da Diversidade às Diferenças: Proposta e Reflexões a Partir de um EstágioDocência na Graduação em Administração. Revista Interdisciplinar de Gestão Social, v. 6, n. 1, 2017.

PETRI, V. A diferença no discurso e o discurso da diferença. In: Bragança, S.; Parker, M. Igualdade nas diferenças: os significados do "ser diferente" e suas repercussões na sociedade. Porto Alegre: EDIPUCRS, 2009.

PISCITELLI, A. Recriando a (categoria) mulher? In: ALGRANTI, L. (Org.) A prática feminista e o conceito de gênero. Textos didáticos, n. 48. Campinas: IFCH/Unicamp, 2002.

PISCITELLI, A. Interseccionalidades, categorias de articulação e experiências de migrantes brasileiras. Revista Sociedade e Cultura, v. 11, n. 2, jul/dez. 2008.

POMPEU, S. L. E.; SOUZA, E. M. A produção científica sobre sexualidade nos estudos organizacionais: uma análise das publicações realizadas entre 2005 e 2014. Revista Organizações e Sociedade, v. 25, n. 84, p. 50-67, 2018.

POMPEU, S. L. E.; E. M. SOUZA. A Discriminação Homofóbica por meio do Humor: naturalização e manutenção da heteronormatividade no contexto organizacional. Revista Organizações e Sociedade, v. 26, n. 91, p. 645-664, 2019.

RIBEIRO, D. O povo brasileiro: A formação e o sentido do Brasil. São Paulo: Companhia das Letras, 1995.

RIBEIRO, D. O que é lugar de fala? Coleção Feminismos Plurais, Belo Horizonte: Editora Letramento, 2017.

ROSA, A. R. Relações Raciais e Estudos Organizacionais no Brasil. Revista de Administração

Contemporânea, v. 18, n. 3, p. 240-260, 2014.

SAGESSE, G. et al. Marcadores sociais da diferença: gênero, sexualidade, raça e classe em perspectiva antropológica. São Paulo: Editora Gramma, 2018.

SANTOS, B. S. A construção multicultural da igualdade e da diferença. Oficina do Centro de Estudos Sociais, n. 135. Coimbra: Colégio de S. Jerónimo, 1999. 
SCOTT, J. Gênero: uma categoria útil de análise histórica. Educação e Realidade, v. 20, n. 2, p. 71-99, 1995.

SILVA, R. A.; HELAL, D. H. Ageismo nas Organizações: Questões para Debate. Revista de Administração IMED, v. 9, n. 1, p. 187-197, 2019.

SOUZA, E. M. Poder, diferença e subjetividade: a problematização do normal. Revista de Estudos Organizacionais e Sociedade (FAROL), n. 1, p. 104-143, 2014.

SOUZA, E. M. A Teoria Queer e os Estudos Organizacionais: Revisando Conceitos sobre Identidade. Revista de Administração Contemporânea, v. 21, n. 3, p. 308-326, 2017.

STEINFIELD, L. et al. Transformative intersectionality: Moving business towards a critical praxis. Journal of Business Research, v. 100, p. 366-375, 2019.

ZAMBONI, M. Marcadores Sociais da Diferença. Sociologia: grandes temas do conhecimento (Especial Desigualdades). São Paulo, v. 1, p. 14-18, 2014. 